\title{
Preparation of composite materials based on natural zeolite containing different minerals and their characteristics
}

\author{
J. F. M. Ibrahim¹, L. A. Gömze ${ }^{1,2,3}$ \\ ${ }^{1}$ Department of Materials Sciences and Engineering, University of Miskolc, Hungary; \\ jamalfadoul@gmail.com,femgomze@uni-miskolc.hu \\ 2IGREX Engineering Service LTD, Hungary \\ ${ }^{3}$ Tomsk State University, Russian Federation
}

Generally speaking, the research development in ceramics and especially in ceramic matrix composite has attracted high interest lately [1-10], because of the ability to synthesis advanced ceramics with superior characteristics and outstanding performance when compared to polycrystalline ceramics which normally experience lower mechanical behaviour such as brittle fracture. A number of works have been conducted based on ceramics strengthen ceramic-matrix composites which exhibit improved mechanical properties such as mechanical strength [11], fracture toughness [12], wear-resistance and creep resistance [13], moreover, enhancement in some functional characteristic such as optical behavior, magnetic behavior and heat conductivity is also reported [14].

Strengthening a ceramic matrix with reinforcement in various shape, for instance, whiskers, fibers, or particulates is one of the most efficient techniques used to improve several behaviors, the basic challenge is the prevention of agglomeration by ensuring homogeneous distribution of the reinforcement. Among ceramic-matrix composites zeolites matrix composites have been highly used in the synthesis of the composite materials due to their magnificent properties, for example, their high surface area, their high ions exchange capacity, good adsorption efficiency and their capability to host a secondary phase in their structure. Excellent improvement of many properties of zeolite-based ceramic composites has been attained. Yasumori A. et al. [15] reported that titania strengthens zeolite composite can highly adsorb polar molecules. Furthermore, an enhancement in mechanical behaviors in zeolite reinforced ceramic composites had been mentioned in various research works [16].

In this research work, zeolite-reinforced alumina composite materials were produced using mechanical activation and reactive sintering technique. The morphology and microstructure of the raw materials and the final product have been examined using X-ray diffraction (XRD) and scanning electron microscopy (SEM). Furthermore, the effect of raw materials composition, sintering temperature on the shrinkage density, weight loss, and porosity was determined. Synthesis of these types of materials using relatively inexpensive starting raw materials could lead to the preparation of economically cost-effect materials with superior properties.

\section{References}

1. Gömze L. A. et al 2013 IOP Conf. Ser.: Mater. Sci. Eng. 47 012030. https://doi.org/10.1088/1757899X/47/1/012030

2. Kurovics E. et al 2016 IOP Conf. Ser.: Mater. Sci. Eng. 123 012058. https://doi.org/10.1088/1757899X/123/1/012058

3. Ibrahim J. F. M., Kurovics E., Gömze L. A. New Zeolite-Alumina Composite Materials - Development And Investigation, Preparation of Ceramic Materials Proceedings of the XIIIth International Conference, Jahodná, 25-27th June, 2019. ISBN: 978-80-553-3314-4

4. Kotova et al 2017 IOP Conf. Ser: Mater. Sci. Eng. 175 012002. https://doi.org/10.1088/1757899X/175/1/012002

5. Emese Kurovics et al 2019 IOP Conf. Ser: Mater. Sci. Eng. 613 012025. https://doi:10.1088/1757899X/613/1/012025

6. Buyakov A. S. and Kulkov S. N. 2017 IOP Conf. Ser.: Mater. Sci. Eng. 175 012025. https://doi. org/10.1088/1757-899X/175/1/012025

7. Ibrahim J. F. M. et al 2019 Építőanyag-JSBCM 71 (4) 120. https://doi.org/10.14382/epitoanyag-jsbcm.2019.21

8. Kurovics E., et al 2019 Építőanyag-JSBCM 71 (4) 114. https://doi.org/10.14382/epitoanyag-jsbcm.2019.20

9. Shchemelinina T. et al 2019 Építőanyag-JSBCM 71 (4) 131. https://doi.org/10.14382/epitoanyag-jsbcm.2019.23

10. Ibrahim J. F. M. et al 2019 IOP Conf. Ser: Mater. Sci. Eng. 613 012009. doi: 10.1088/1757899X/613/1/012009.

11. Jiang D. L., Huang Z. R. 1999 Key Engineering Materials 159 Trans Tech Publications 25 http://dx.doi. org/10.4028/www.scientific.net/KEM.159-160.379 
12. Sternitzke M., et al. 1997 Acta materialia 45 (10) 3963. http://dx.doi.org/10.1016/S13596454(97)00113-4

13. Deng Z. Y., et al. 1999 Journal of the American Ceramic Society 82 (4) 944. http://dx.doi. org/10.1111/j.1151-2916.1999.tb01858.x

14. Ibrahim J. F. M., Kurovics E., and Gömze L. A. Synthesis, characterization and rheological properties of alumina-zeolite mixtures // MultiScience - XXXIII.
microCAD International Multidisciplinary Scientific Conference University of Miskolc, 23-24 May, 2019, ISBN 978-963-358-177-3

15. Yasumori, et al. 2015 Molecules 20 (2) 2349. https://doi.org10.3390/molecules20022349

16. Iqbal, Nida, et al. 2016 Ceramics International 42 (6) 7175. https://doi.org/10.1016/j.ceramint.2016.01.107 